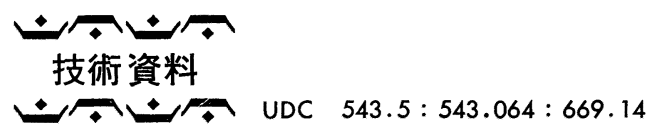

\title{
鉄鋼の表面分析の最近の進歩
}

\author{
広川吉之 助*
}

\begin{abstract}
Recent Development of Surface Analysis of Iron and Steels
\end{abstract}
\section{Kichinosuke HirokAwA}

\section{1.はじめに}

鉄鋼の表面分析は半導体関係の表面分析とならんで近 年多大の進歩をなしとげた. 半導体材料はその中の電子 や原子などの動きが材料の機能を支配すること, 顕微鏡 下における観察が必要な（組み立て作業などで）小型デ バイスが多く，そのためにも表面局所分析が要求されて 来た ${ }^{11}$. これに対し鉄鋼材料は強度と耐環境性の問題, すなわちより強い材料の要求から表面分析が研究され, 応用されて来たとしてよい。

具体的には, やはり表面局所分析が鉄鋼の分野で要求 される，それは製造治金関係では熱間加工性，過熱脆 化, 溶接割れなどに関連し, 熱処理の立場から見ると焼 入性, 焼もどし脆性, 焼割れ, 粒界割れ, 析出物, 更に 使用上から考えてヒートチェック, はんだ脆性, 表面偏 析, 表面処理, おくれ破壊, 低温脆性など 微量成分の ( $\mathrm{P}$ や $\mathrm{S}$ など) 局部的挙動が強度に影響を与えるからであ ろち.

このようなある成分元素の局部的挙動に対して過去20 年間もつとも広く応用されて来た測定機器すなわち機器 分析法（測定の性格上機器分析とならざるを得ないが） は現在すでに定量法が確立されていると認められている EPMA (Electron Probe Micro Analysis) である. その ため EPMA に関する報告, 解説も数多い. そこでここ では EPMA に関する説明はほとんど行わず, EPMA 以 後の表面分析法について述べる.

まず表面分析法の範囲に2)3 現在どんな方法が入れら れているかを見ると,さながら略号の羅列の感を与える. まず EPMA, SIMS (Secondary Ion Mass Spectroscopy), XPS (X-ray Photoelectron Spectroscopy), AES (Auger Electron Spectroscopy), UPS(Ultraviolet Photoelectron Spectroscopy), RHEED(Reflection High Energy Electron Diffraction), LEED (Low Energy Electron Diffraction), ISS (Ion Scattering Spectroscopy),
APS (Appearence Potential Spectroscopy), FIM(FieldIon Microscopy), RBS (Ratherford Backscattering Spectroscopy), SEM (Scanning Electron Microscopy), TEM Transmission Electron Microscopy), STEM (Scanning Transmission Electron Microscopy)などが比較 的多くの人の念頭に浮かんで来る. しかもこのほか Conversion Electron Mössbauer Spectroscopy(CEMS) や Laser Raman Spectroscopy, Ellipsometry4), Modulation Spectrometry5) などが 表面の 解析に応用されてい る.

しかし, 鉄鋼試料を対象にかつ機器分析 ${ }^{6)}$ ８) または分 析化学的な立場からどのよらな表面分析法が応用され得 るかを考えると, (1)得られる情報が電子, 原子, 分子レ ベルであること, (2)情報が適当なエネルギや空間分解能 をもつて直接原子. 分子の存在, 実体を定量的に示すこ と, (3)多くの試料, 多くの元素に対して共通的な操作 で応用できることが主な要望事項となる．このような要 望条件をかなり満足してくれるのは分光化学的方法が主 となり，それは EPMA であり, SIMS とくに IMMA (Ion Microprobe Mass Analysis), AES, ESCA(Electron Spectroscopy for Chemical Analysis) とくに XPS で ある ${ }^{9}$. これらの方法で得られる情報の一部をさらに確 認するためか，すでに目的とする元素とその状態が画一 的である程度予想されていたりする場合にその他の方法 が相補的または単独に応用される。

表面分析で取り扱ら範囲を逆に現実の装置の空間分解 能の側から見ると図 1 のよらに，おおよそ見ることがで きる.そして定量性と言う立場から見ると，すでに ZAF 法を基礎として一応定量法が確立されている EPMA に 比較すると今一つの状態にある.

現在表面測定ならびに表面研究に応用されている各種 方法は単独に用いるより組み合わせて使用する方が効果 的であると言われている10). しかしその組み合わせの仕 方によつては測定条件や測定データの解釈の上で問題が

昭和 56 年 1 月 7 日受付 (Received Jan. 7, 1981)（依頼技術資料）

* 東北大学金属材料研究所 工博 (The Research Institute for Iron, Steel and Other Metals, Tohoku University, 2-1-1 Katahira Sendai 980) 


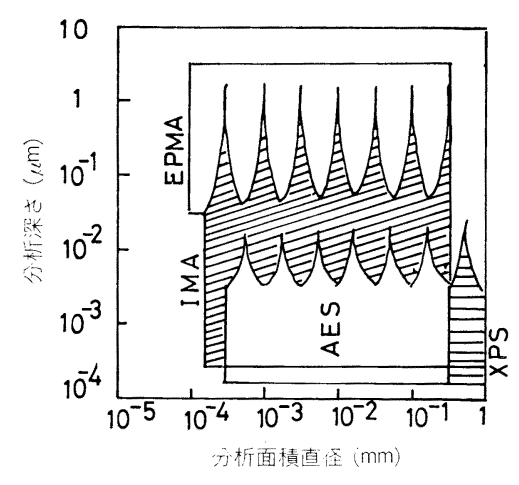

図 1 表面分析で分析され得る深さと面積

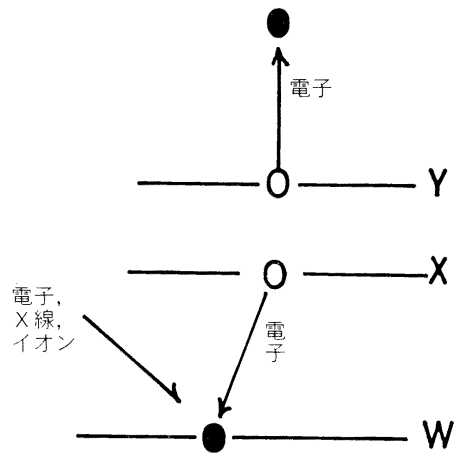

図 2 WXYオージェ励起過程
生ずる場合もあることに注意する必要があるう。また動 的な測定も当然要求されて来ることも多いので測定雾囲 気 (真空度ならびに真空の質も含む), 加熱, 冷却, そし て破断や研磨などの機械加工ができることが表面測定機 器 ${ }^{11)}$ のアクセサリーとして重要となる.

一方人間の希望として表面での現象などを自分の眼で 見たいといら点から高分解能, 高輝度の SEM 像などを 観察し，同時に原子の存在状態とその量を見る方向に表 面分析法は進むであろらし, 現在も分析電顕などとして それらの要求は少しずつ満たされ始めている12. そして 表面といら性格上かつ前述の要望事項を満足するような 分析機器は大型化し, その割合には従来の分析機器に比 較して与兄てくれる情報量が少ないような感じを一般の 人々は受けとるかと思われる。 しかも現在までこれら新 しい表面分析法の結果，非常に新しい何かを発見したと いらより，従来予想されていたことを確認したといら意 味での貢献度も大きく評価されるべきと思う。この確認 を基礎として，さらに新たな知見を表面ならびに界面に， この鉄鋼表面分析法の各種手法が与えてくれることを希 望している.

本項では前に述べた要望事項から SIMS (IMMA) AES そしてXPS そついて, 原理や装置・自体の説明は 概要にとぞめ，その方法の応用と特質に重点を置いて， しかも対象試料を鉄鋼にとどめて説明したい。

\section{AES (Auger 電子分光法) ${ }^{13}$}

Auger 電子の発生は物質に電子線, X線ならびにイオ ン線などを照射した場合に生ずるが，ここでは特に，こ とわらないかぎり電子線を励起源とした場合にかぎる.

Auger 電子の発生原理は図 2 亿示すように物質に電子 線，X線，イオン線などを照射した場合，原子の内核レ ベルたとえばW準位に空孔が生ずるとする，その空孔に $\mathrm{X}$ レベルからの電子が落ちこみ, その時放出されるェネ ルギを受けてY殼からの電子が真空領域に放出される場 合, この電子を WXY Auger 電子という。その電子の
持つエネルギは近以的に $E_{\mathrm{WXY}}=E_{\mathrm{W}}-E_{\mathrm{X}^{\prime}}-E_{\mathrm{Y}^{\prime}}-\phi_{\mathrm{A}}$ で 示される。 $E_{\mathrm{W}}$ はW準位のエネルギ， $E_{\mathrm{X}^{\prime}} ， E_{\mathrm{Y}^{\prime}}$ は原子 がイオン化した状態での $\mathrm{X}, \mathrm{Y}$ 準位のエネルギ(一般には 原子の $\mathrm{X}, \mathrm{Y}$ 準位のイオン化エネルギと見て大差ない, ) $\phi_{\mathrm{A}}$ は分析器の仕事関数である。このように発生した Auger 電子は Auger 電子分光器で測定される. 古くは AES-LEED の測定が可能である Germer 型の分光器の 応用 ${ }^{14)}$ から近年は高輝度の CMA (Cylindrical Mirror Analyzer)による測定が多くなりかつ電子線を試料表面 上に $\mu \mathrm{m}$ 径位に結ばせるマイクロ AES の測定が増して いる ${ }^{15)}$.

AES の特長は(1) Li より重い元素が比較的感度差が少 なく測定できること，(2)電子ビームを $5 \mu \mathrm{m}$ 径程度にし ぼり前述のようにいわゆるマイクロ AES が可能である こと, (3) AES と電子線の励起条件が異なるが同一装置内 で希望個所の SEM 像も Auger 電子像の観察が可能な ことなどである. 一方 (1) AES シグナルが高い:゙ックグ ランドの上に乗つているため近年はその微分曲線より, シグナル強度を測定することが一般的である ${ }^{16)}$ ．そのた めシグナル強度を測定して定量化を行う場合には問題が 残る. (2)AES の測定は後で述べるXPS と同様にその 測定する深さは図 3 に示す。いわゆる “Universal cur$\mathrm{ve}^{17)}$ の数 $\mathrm{KeV}$ 以内の電子の運動エネルギ範囲，すな わち厚さ数十 $\AA$ 以下の平均值と見なければならない。そ のため定量に際して必要な標準試料の作製・調整が困難 か不可能に近い，また，最初に内殼レベルの電子を真空 領域にたたき出すイオン化確率 (ionization cross section ${ }^{18)}$ ) は一次電子線のエネルギに大きく影響(図 4 参照) を受ける．そのため定量分析には現在のところ必ずある 程度の仮定が入り，かつ誤差をともなう。といつたこと を念頭に置かなければならない，定量法はこのような点 を考慮されながら，他の表面分析の場合と同じくある特 定の試料群に対しては標準試料群を準備して検量線を作 製する場合と相対感度係数をある元素に対して求め，そ れを使用する方法が一般的である1920)。しかし，物理的 

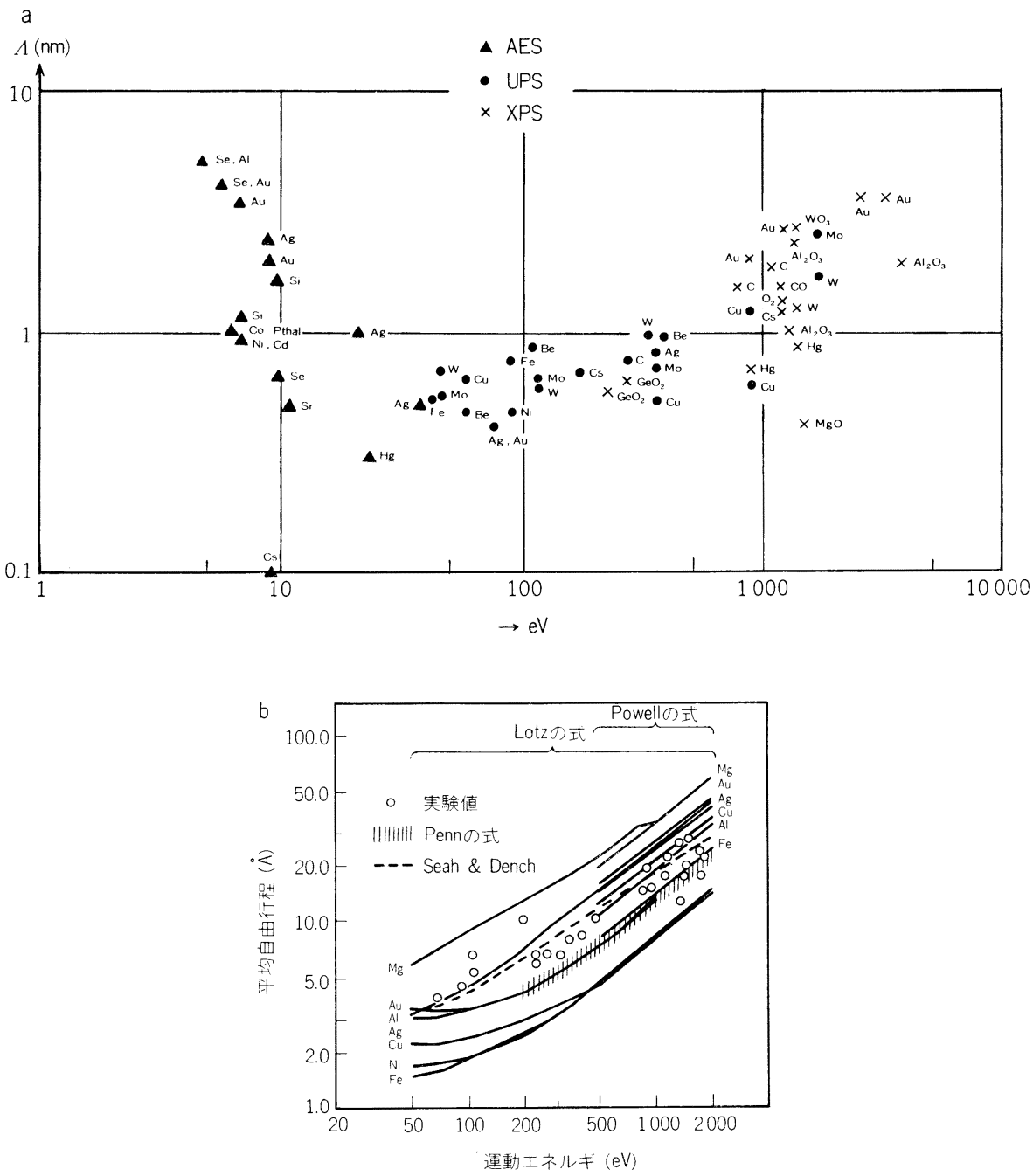

図 3 各種物質中での電子の運動エネルギ $(\mathrm{eV})$ とその平均自由行程 $(\lambda), \mathrm{a}$ と各種モデル計算による電子の平均自由行程, b

なパラメータの決定や収集が今一つ十分ではなくその定 量誤差は土30\% ほどを認めなければならない。

しかし電子ビームを細くしぼることができ，かつ比較 的高輝度で Auger 電子強度の測定が可能であり, しか も図 5 に示すよらにスペクトル線のプロフアイルから, その元素の状態21)が推測できる可能性もあるので, 例え ば鉄鋼における脆性破壊に関与する元素の測定にはもつ とも適当な分析法の一つである.

Auger 電子分光法の応用例として微量元素の表面偏 析挙動, 同じく粒界偏析量とその定量, 熱間加工性や焼 なまし割れ，焼もどし脆性などに対するこれらの微量元 素の効果などである. そして近年はマイクロ AES によ る検討が活発に進められている. これらの例としては表 面偏析については非常に多くの報告があり，たとえば
$\mathrm{Fe}-\mathrm{Ni}$ 合金 ${ }^{22}$ を $500^{\circ} \mathrm{C}$ で加熱した結果は図 6 に示され るよらに Pや $\mathrm{S}$ の表面偏析は $\mathrm{Ni}$ 量の影響を受け，Pの 偏析量が表面で最大となる時間 $\left(500^{\circ} \mathbf{C}\right.$ 等温加熱 $)$ は $\mathrm{Ni}$ 量の多い方が早いこと, そして S の Auger ピーク の成長とともに P のピークが減少することが認められ た.これと同様な結果が単結晶を始め $\mathrm{Fe}$ の表面に打け る偏析挙動として古くから報告されている ${ }^{23)}$. 粒界破面 にPが偏析していることもマイクロ AESで確認され24), たとえば $0.75 \mathrm{Mo}-0.027 \% \mathrm{P}$ のような組成の鉄鋼試料に ついては図7のような結果が得られており, 粒界破壊の 部分のみについて，Pの偏析が検出され，これと焼もど 乙脆性の脆化度 $(\Delta \mathrm{v} T \mathrm{~s})$ の間に図 8 に示すような明確 な対応があらわれていることも認められた。.もちろんマ イクロ AES により破面などに観察される析出物の同定 


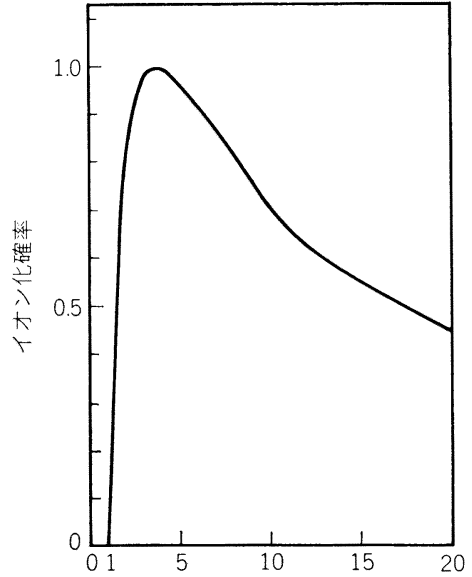

1次電線エネルギとイオン化エネルギの比

図 4 オージェ電子発生のイオン化確率と, 1 次電 子エネルギとイオン化エネルギの比との関係例18)

も可能である ${ }^{26)}$. 一方焼結体や表面処理鋼板，すなわち 不働態皮膜の組成決定 ${ }^{27)}$ PFS (Tin Free Steel) の表 面に存在する Cr の状態が表1のように調べられている 19).

電子線照射による Auger 電子分光での問題の一つに 試料の照射損傷がある. とくにビーム状にしばつた電子 線は高い電流密度を与えるため, 極力短時間, 高感度の 測定を行わなければならない，一方 AES のみならず後 で述べるXPS でも同様であるが深さ方向への分析を行 う場合に $\mathrm{Ar}^{+}$などによるスパッタリング剝離が採用さ れることが多い，この場合には試料によつて，分解，還 元そして選択スパッタリングが生ずることがよく知られ ているので注意を要する.

なお本項では定量分析 ${ }^{25)}$ 法についてはくわしく触れな かつたが表面測定の定量的解釈には現在のところある種 の仮定が入つて来ることは止むを得ない，ただその仮定 の意味をよく確認し定量的解析のどの時点で仮定を導入 し，それはなぜかをきちんと表現しておかないと，実験 結果に間違つた解釈や異様な印象を与えるので注意が必 要である.

3. IMMA (Ion Microprobe Mass Analysis), SIMS (Secondary Ion Mass Spectroscopy)

EPMA に続いて,その欠点をおぎならのではないかと 期待され, 登場して来た表面分析法に SIMS がある・こ の SIMS のらちとくに比較的高エネルギのイオンビー 么（約 $10 \mathrm{KeV}$ 以上）を試料上に結ばせて, 表面局所 分析を行い2 次イオン像が得られる IMMAが鉄鋼関係 で応用されている.この IMMA では EPMA では不可 能か困難であつた水素を始め軽元素の分析が 可能であ り，かつEDMA に比較してはるかに高感度であるとい
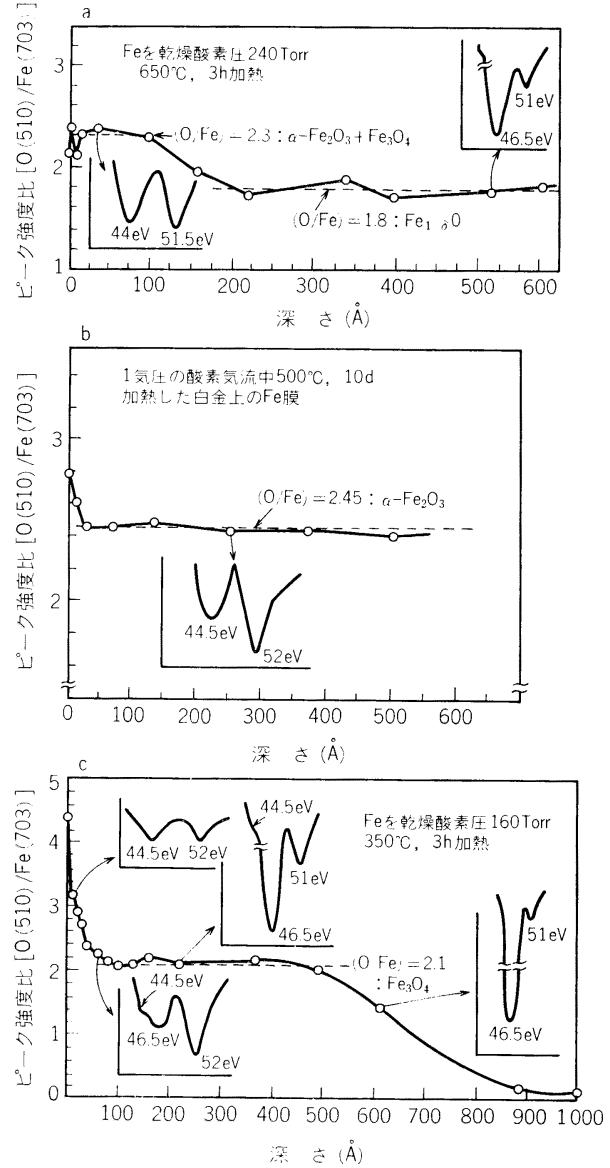

図 5 鉄酸化皮膜の深さ方向に打けるオージェ・プ

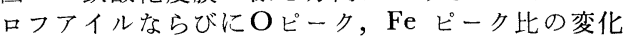
a $\left.: \mathrm{Fe}_{1-\mathrm{x}} \mathrm{O}, \mathrm{b}: \alpha-\mathrm{Fe}_{2} \mathrm{O}_{3}, \mathrm{c}: \mathrm{Fe}_{3} \mathrm{O}_{4}{ }^{21}\right)$

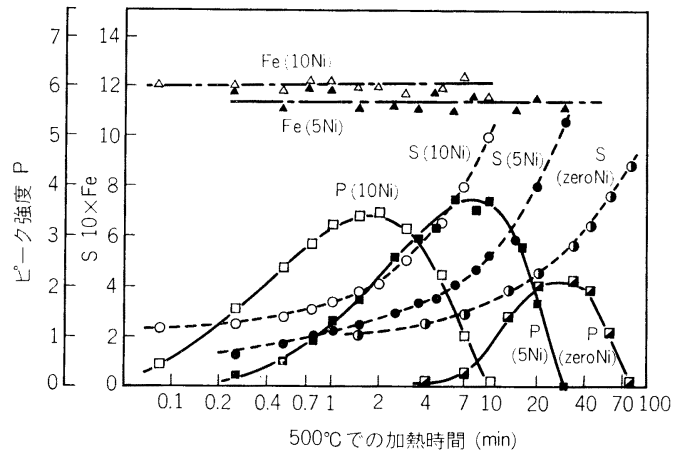

図 $6 \mathrm{Fe}-\mathrm{Ni}$ 合金を $500^{\circ} \mathrm{C}$ に加熱した時のオージ エピーク強度の変化 ${ }^{22)}$

(10Ni) : 9.62 wt $\% \mathrm{Ni}, 0.073$ wt $\% \mathrm{P}$.

(5Ni) : 5.35 wt $\% \mathrm{Ni}, 0.082$ wt $\% \mathrm{P}$.

(zeroNi) : $0.05 \%$ wt $\% \mathrm{Ni}, 0.077$ wt $\% \mathrm{P}$. 


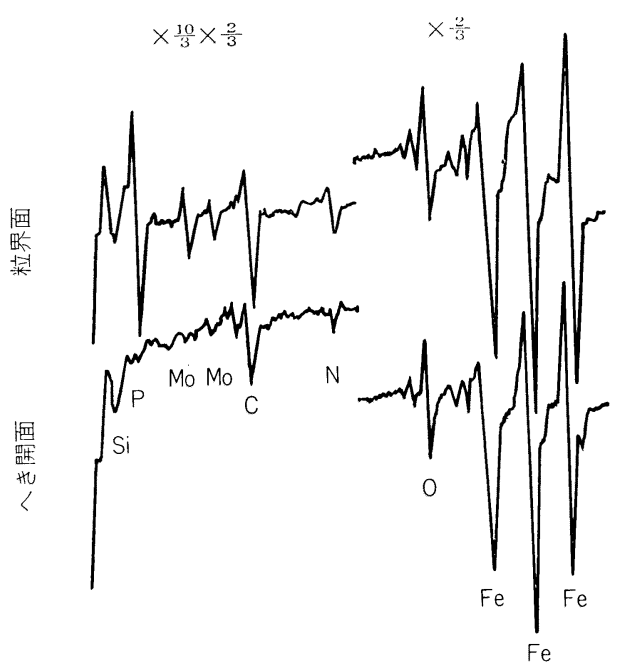

\begin{tabular}{|c|c|c|}
\hline & 粒 界 & へき界 \\
\hline $\mathrm{P} / \mathrm{Fe}$ & 0.160 & $<0.010$ \\
\hline $\mathrm{Mo} / \mathrm{Fe}$ & 0.061 & 0.012 \\
\hline $\mathrm{C} / \mathrm{Fe}$ & 0.112 & 0.051 \\
\hline $\mathrm{N} / \mathrm{Fe}$ & 0.041 & 0.018 \\
\hline $\mathrm{O} / \mathrm{Fe}$ & 0.382 & 0.368 \\
\hline
\end{tabular}

$0.75 \mathrm{Mo}-0.027 \mathrm{P}, 600^{\circ} \mathrm{C} \times 100 \mathrm{~h}$

図 7 破面のマイクロプローブ・オージェスペクト ルの例24)

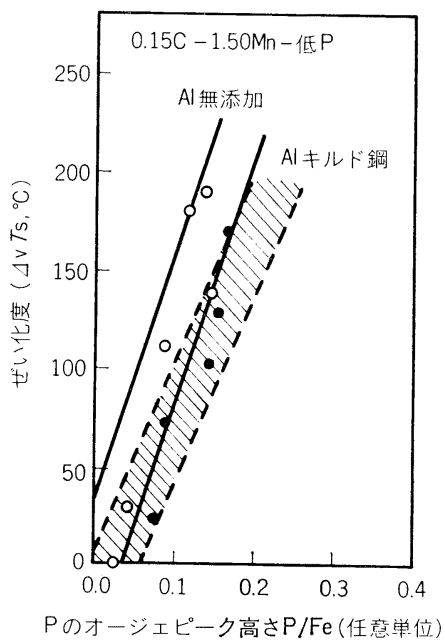

図 $8 \mathrm{P}$ の䊀界偏析量とぜい化度 $(\Delta \mathrm{v} T \mathrm{~s})$ の関係 $\left.{ }^{24}\right)$

ら特長を持つている. もちろんマススペクトルを測定す るため同位体比の測定なども可能である.

IMMA はイオンによるスパッタリングで物質の元素 イオン化を行い，質量分析で，そのフラグメントの決定 と強度測定を実施するわけである。そ狆はいわゆるHE-
表 1， Fe-25-Cr 合金鋼の深さ方向に対する $\mathrm{Cr}$ の 存在状態

\begin{tabular}{|c|c|c|c|}
\hline \multirow[b]{2}{*}{$\begin{array}{l}\text { スパッタリ } \\
\text { ング時䦓 }\end{array}$} & \multicolumn{2}{|c|}{ Cr のオージェ遷移間の } & \multirow{2}{*}{$\begin{array}{l}\mathrm{Cr} \text { の存在状 } \\
\text { 態* }\end{array}$} \\
\hline & $\begin{array}{l}\mathrm{L}_{3} \mathrm{M}_{2,3} \mathrm{M}_{2,3} \sim \\
\mathrm{L}_{3} \mathrm{M}_{2,3} \mathrm{M}_{4,5}\end{array}$ & $\begin{array}{l}\mathrm{L}_{3} \mathrm{M}_{2,3} \mathrm{M}_{4,5} \sim \\
\mathrm{L}_{3} \mathrm{M}_{4,5} \mathrm{M}_{4,5}\end{array}$ & \\
\hline 0 分 & 37 & 45 & $\alpha-\mathrm{Cr}_{2} \mathrm{O}_{3}$ \\
\hline $1 " 1$ & 38 & 46 & \\
\hline $2 " \prime$ & 33 & 45 & $C=\Omega^{\prime \prime} C_{n}$ \\
\hline $3 "$ & 39 & 43 & $\alpha-\mathrm{Cr}_{2} \mathrm{O}_{3}$ or $\mathrm{Cr}$ \\
\hline $5 " \prime$ & 40 & 42 & $\mathrm{Cr}$ \\
\hline $7 "$ & 41 & 40 & \\
\hline$\underset{\alpha-\mathrm{Cr}_{2} \mathrm{O}_{3}}{\mathrm{Cr}}$ & $\begin{array}{c}40 \\
38 \sim 39\end{array}$ & $\begin{array}{c}41 \\
45 \sim 46\end{array}$ & \\
\hline $\begin{array}{ll}* & \text { Cr } \text { がメ } \\
& \text { の存在状 }\end{array}$ & の $\mathrm{Cr}$ と $\alpha-\mathrm{Cr}_{2}$ & ${ }_{2} \mathrm{O}_{3}$ の状態しかとら & ないと仮定した時 \\
\hline
\end{tabular}

SIMS (High Energy SIMS) また HDSIMS (High Damage SIMS)の範鱚に入り, 数 $\mathrm{KeV}$ 以下のエネルギ を持つイオンで極表面層のスパッタリングを行う SSIMS (Static SIMS) または LDSIMS (Low Damage SIMS) と少々異なる ${ }^{3132)}$. すなわち $10 \mathrm{KeV}$ またはそ れ以上のエネルギを持つイオン $\left(\mathrm{Ar}^{+}, \mathrm{O}_{2}{ }^{+}, \mathrm{N}_{2}{ }^{+} \cdots\right)$ を 試料表面上に焦点を結ばせ，その局所をスパッタリング する.この IMMA はスパッタリングにより表面からの 剥離部分を質量分析器で測定するためつぎのような特長 を持つている. (1)EPMA に比較して検出感度が高く, 軽元素の分析が可能である.ただし $\mathrm{H} や \mathrm{~N}$ に対しては特 殊な場合以外鉄鋼で取り扱うには感度不足である。(2薄 膜ないし，極表面層の分析が可能である。しかしIMMA による測定では初期表面污染層におけるスパッタリング 強度の異常性を経て，スパッタリングが定常状態になつ た場合以後のイオン強度を測定することはごく表面の分 析というょり bulk の組成を求めることになる. (3)同位 体比の測定が可能であるなどである。一方欠点としては (1)ミクロ的には非破壊分析ではない. (2)試料の形状, 状 態 ${ }^{46)}$, 結晶方位, 吸着物や酸化物膜存在の有無で 2 次イ オンの収率（とくに $\mathrm{Ar}^{+}$による場合）が変化する. (3) 定量性から見ると元素による相対感度俰数の変化が大き い場合がある。などである。

しかしこれらの欠点を和ぎなつて余りある有効な応用 が鉄鋼試料に対して行われている.

一次イオンとして $\mathrm{Ar}^{+}$より $\mathrm{O}_{2}^{+}$や $\mathrm{N}_{2}^{+33)}$ の方が 2 次イオン強度の強さ, 安定性, 収率ならびにスパッタ表 面の平滑度などの点で効果がある。このような効果は $\mathrm{O}_{2}^{+}$分圧をある程度以上高めた雾囲気中での $\mathrm{Ar}^{+}$スパ ッタリングでも認められる34). そして定量法の一つであ る LTE $^{35)}$ (Local Thermal Equilibrium) 法の応用が容 易である点からこれら反応性ガスが実用上使用されてい る.

一方スパッタリングやスパッタリングによるイオン化 


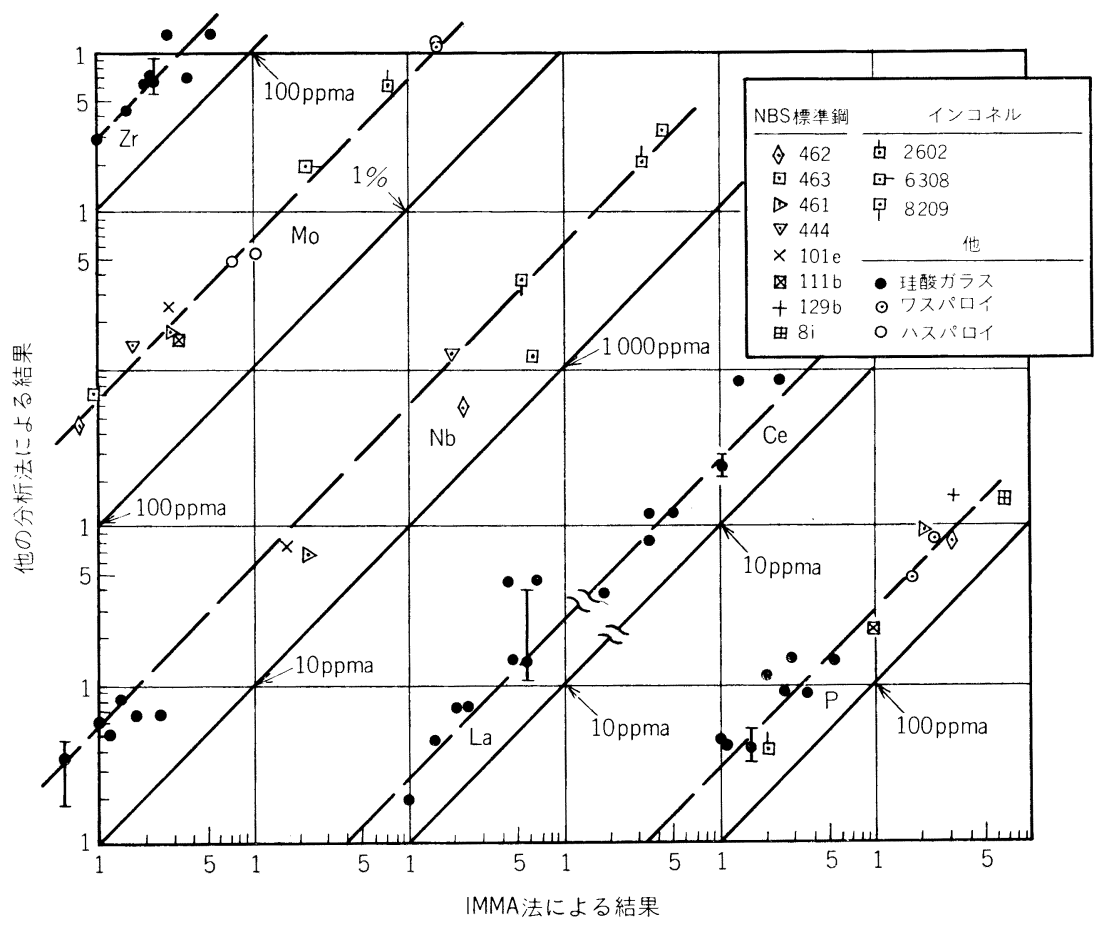

図 9 L T E 法による結果と他の方法による結果の比較例 35$)$

(2 次イオン放出過程) は $\mathrm{Ar}^{+}$を使用した場合について その放出機構が説明されていることが多い，そして現在 までのところ 2 次イオンの生成機構を総括的にすべてを 適確に説明できる状態にはなつていない，現在はこの 2 次イオン生成機構に対し, (1) CASTAING らによるイオン がターゲットの外側でオージェ遷移によるイオン化過程 を経る36)37). (2)同じく SCHROEER ら ${ }^{38)}$ による量子力学的 遷移モデルとして対象が金属に限られるモデル，(3)イオ ンが固体内で発生するとする同一化合物が化学結合を切 断され，正負両イオンが生ずるとするモデル39)40)，(4)同 じくANDERSEN らにより提唱された局所熱平衡 (LTE) モデル35)などがある．とくに LTE モデルはこれを基礎 とした定量法が提案され，応用されている(1144).

このように 2 次イオン放出機構が明確でないことは IMMA による定量法を困難にしている要因であるとも いわれている. しかし発光分光分析が理論的に光強度と 分析元素の含有量が必らずしも比例関係にないが励起条 件を厳密に設定すれば定量性が保持できる.これと同じ ような点を考慮すれば IMMA も全イオンモニター法な ど43)を採用するなど適当な励起条件を設定すれば定量性 が得られるはずである．事実検量線法ならびに LTE 法 が応用されている.これら定量法に関するくわしい説明 はここでは触れないが，熱力学的分析法では $30 \%$ 程度 の誤差, 検量線法では条件をよく設定すればそれより少
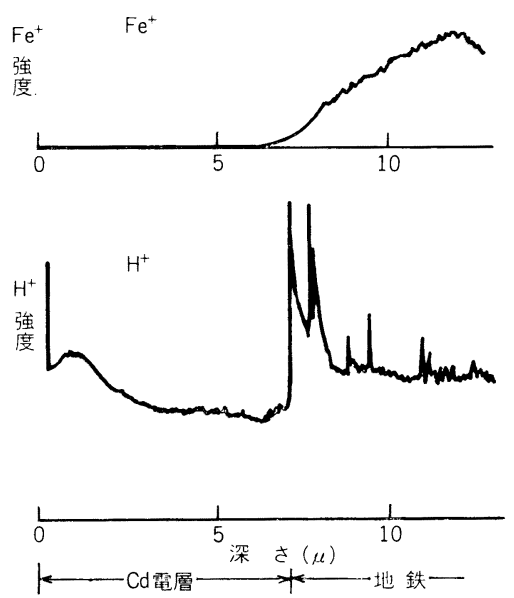

図10 めつきした $\mathrm{Cr}-\mathrm{Mp}$ 鋼におけるHの分析45)

ない誤差で定量ができる.

鉄鋼関係への応用はすでに IMMA の出現時から数多 く報告され，LTE 法による NBS 標準試料などの分析 結果が図 9 のように示されている ${ }^{35)}$. また鋼板表面に付 着したBやボロン処理鋼板の分析 ${ }^{43}$ 焼なましや高温酸化 による表面偏析, 図 10 のように水素のめつき境界面に おける偏析の測定 ${ }^{45)}$ などが行われた。 また真空中で破断 

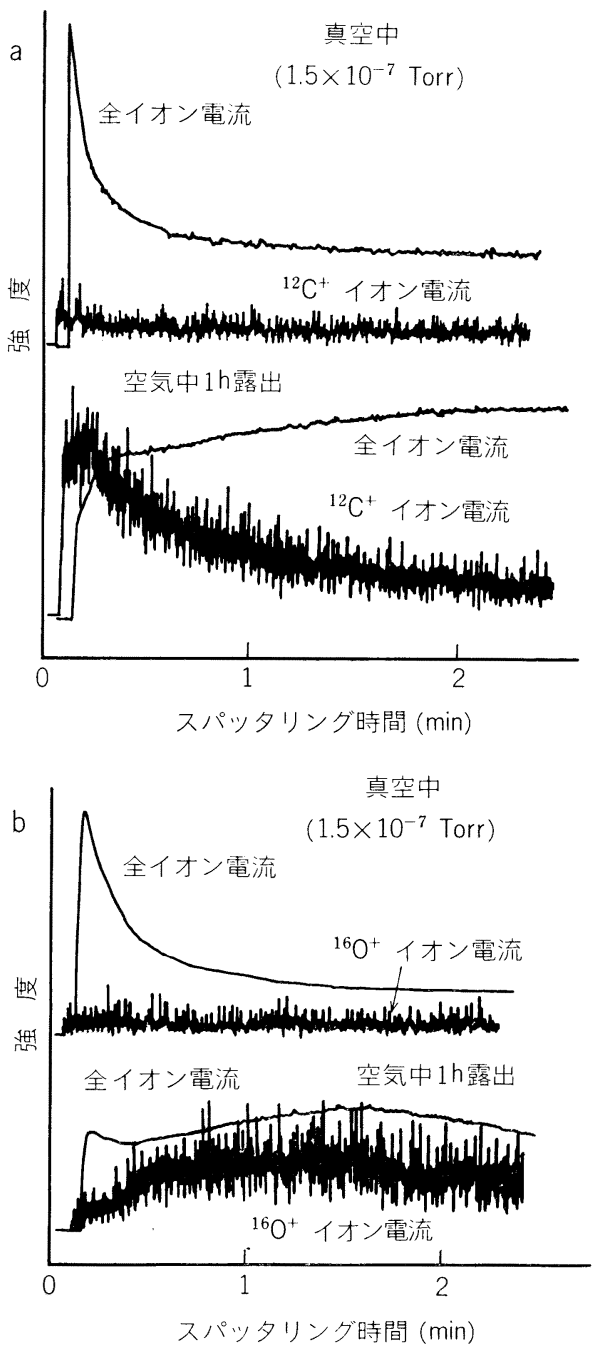

図11 破断面上の $\mathrm{C}(\mathrm{a})$ ならびに $\mathrm{O}(\mathrm{b})$ の深さ方向 の分布とその空気中に放置後の变化 ${ }^{11)}$

した場合の $\mathrm{O}$ と $\mathrm{C}$ の変化が図 11 に示されるようにな る11)など結晶粒界破面に対する応用などもすでに述べた AES の場合と同椂に行われている・もちろん不銹鋼を始 とする各種表面処理鋼板の表面測定など応用も多い. そしてこの IMMA 法は現在も他の表面分析法と同じく 中性粒子や負イオンの応用 47)など基礎研究とともに定量 法に対する地道な研究40)46) も活発に行われている.

一方鉄鋼関係では IMMA に比較して応用が少ないが (定量性に問題があるため)いわゆる Static SIMS (又は Low Damage SIMS) として数 $\mathrm{KeV}$ 以下の一次イオ ン励起で表面層をスパッタリングする技術が表面吸着や 表面酸化の研究に応用され得る.

\section{ESGA (Electron Specctroscopy for Chemical Analysis), XPS (X-ray Photoelectron Spectroscopy $)^{49)}$}

ESCA といらとXPS と UPS (Ultraviolet Photoelectron Spectroscopy）の両者があるが，鉄鋼の場合の 応用性ならびに定量性から見てXPS の方が有効である う.UPS の方は吸着ならびに金属のバンド構造の研究に 有効であるが外殼も含めて内殼レベルの電子状態が多く の元素に対して測定できることからXPS について，こ こでは述べる.

XPS の原理は物質に一定エネルギの X 線を照射した 場合，物質を構成する各元素の電子が，その元素の軌道 の束縛エネルギからとき離れて殼外に飛び出す。その 電子の運動エネルギはX $\mathrm{X}$ 線のエネルギから電子の束糐エ ネルギを差し引いた值にほぼ等しいといら事実に基づい

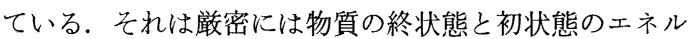
ギ差である. しかし各物質を構成する元素はその化学状 態により，それを構成している電子の束縛エネルギが, わずかずつ変化し，それが XPS スペクトルのなかに化 学シフトやサテライトの形で出現寸る. この化学シフト やサテライトの判定からその元素の状態を, 電子線強度 の測定により定量を行うことができる。ただ現在のとこ ろ ESCA で測定可能な試料上の面積は，マイクロ AES や IMMA と異なり径, 約数 $\mathrm{mm}$ 以上の面積が必要で 西る. Hや He 以外の元素の測定が可能で，かつその状 態の判断もかなりできるが，欠点としては現在のところ 感度が期待されている程よくないこと, 元素によつては スペクトルパターンの変化が状態変化にともなおずそれ 程明瞭でないものもある.

鉄鋼に対する ESCA の応用はこのような長短の特質 から, 不働態皮膜の厚さ, 組成の決定とその状態測定, ならびに表面処理鋼板などへの応用が多(、50)51)522．測定 可能の深さは AES の所で述べたように表面下約 $50 \AA$ 以下の平均的状態である. 図 12 に $\mathrm{Fe}$ の主な酸化物の スペクトルを示す ${ }^{53)}$.これに反し，鉄鋼中の重要元素の 一つである Mn は酸化状態の変化によるスペクトルの 変化は比較的少ない54)。一方 $\mathrm{Ti}$ などは図 13 の上うに 酸化物となると satellite の出現が明膫となる. 図 1450) に示すように不働態皮膜の組成が ESCA で一応知られ ても何故 $\mathrm{Cr}$ の含有量がある程度以上になると表面に $\mathrm{Cr}(\mathrm{OH})_{3 \mathrm{n}} \mathrm{H}_{2} \mathrm{O}$ を主体とする皮膜を構成するかは当然 のことながら XPS 装置は解答してくれないＥSCA の場合も AES の場合と同様に表面の清浄化にあるいは 深さ方向の分析に $\mathrm{Ar}^{+}$スパッタリング（主として 2 $\mathrm{KeV}$ 以下数 $\left.\mu \mathrm{A} / \mathrm{cm}^{2}\right)$ が使用されている. この $\mathrm{Ar}^{+}$ によるスパッタリングは，乙ばしば表面酸化物などの 分解や還元を打こす55)56). 図 15 にはFayalite の $\mathrm{Ar}^{+}$ スハッッタリングによる分解の様子を示したが57)，どのよ 

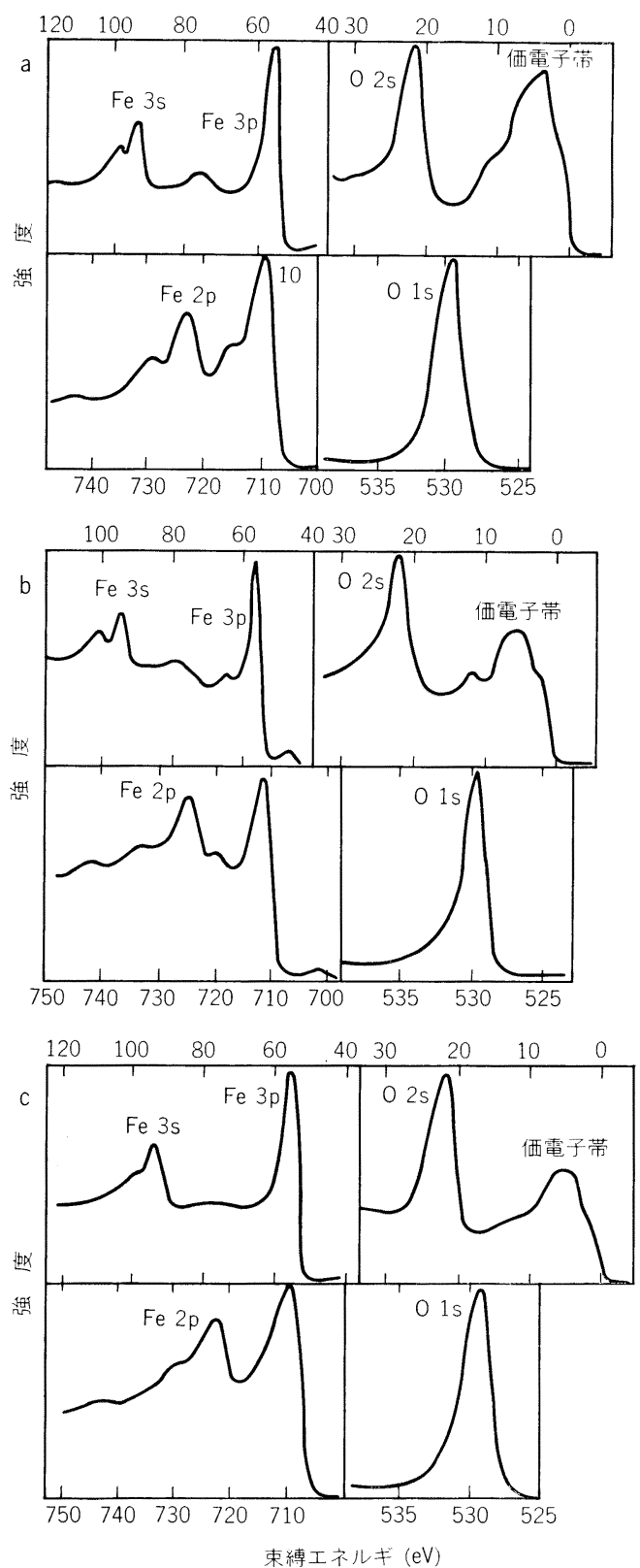

図12 主な $\mathrm{Fe}$ 酸化物の ESCA スペタトル, $\mathrm{a}: \mathrm{Fe}_{1-\mathrm{x}} \mathrm{O}, \mathrm{b}: \alpha-\mathrm{Fe}_{2} \mathrm{O}_{3}, \mathrm{c}: \mathrm{Fe}_{3} \mathrm{O}_{4}$

らな化合物がどのような条件で，どら変わるかなどもあ らかじめ確かめておかないと思わ結論を出すことにも なりかねない。

ESCA では感度が低く微量分析に問題があると述べ たが，現在のところ測定にある程度の時間をかければか なり微量まで測定ができる，例えば空気中で細目やすり で表面研磨した鉄上の $\mathrm{N}$ の加熱による変化の様子が図 16

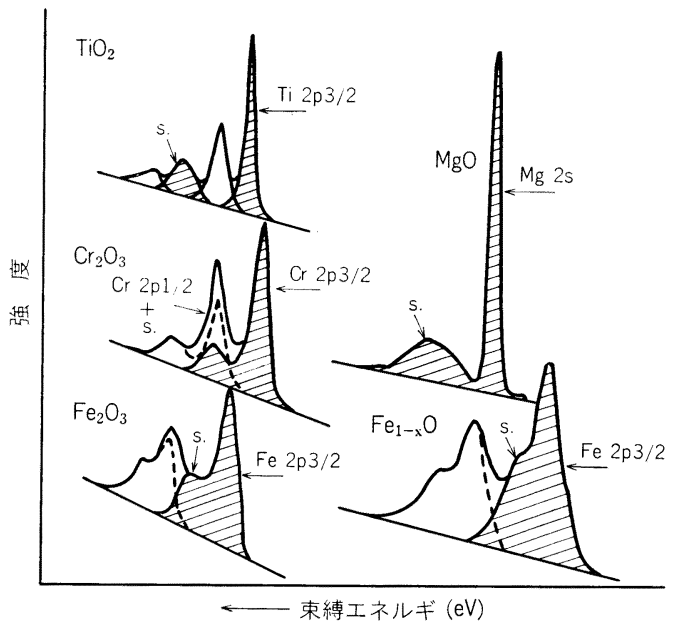

図13各種酸化物ピークに出現するサテライトの例

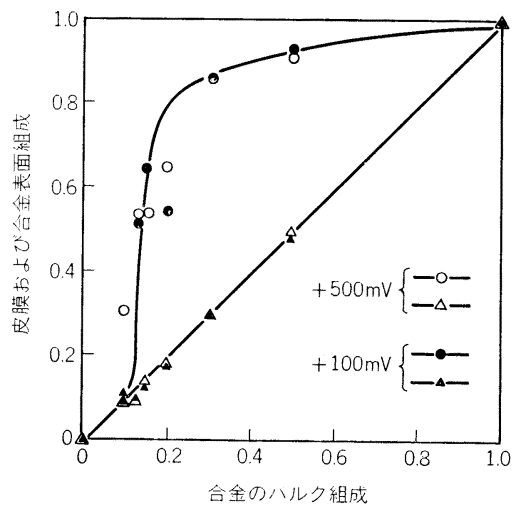

図14 硫酸中で分極した $\mathrm{Fe}-\mathrm{Cr}$ 合金の表面皮膜組 成拉よび皮膜直下の合金表面組成50)

ー○ーおよびーー：皮膜組成，

ー $\triangle$ ーおよびーム-：合金表面組成

(ならびに表 2) のように示される ${ }^{58) \sim 60) . ~}$

ESCA による定量分析は目的とする試料群のなかか ら標準試料に相当する試料を選び自分の選んだ測定条件 で，定量のための各種パラメータを実験的に決定して 使用するが50)，検量線による方法 ${ }^{61)}$ と，強度式に理論 的，実験的に得られたパラメータを代入し，サテライト を含めた電子線強度から相対量を算出する普偏的な方法 (Hirokawa-Ebel's method) 62) 66) がある. 前者は装置 が変わればもちろんのこと, 試料群が変わつたり, 目的 元素が変わると, 応用が不可能となるが, 後者は化学結 合の状態により, その光イオン化断面積が大きく変わる 可能性のある最外殸電子以外は標準のスペクトルパター ンが得られれば広く応用できる利点がある。ただし酸化 物粉末など一般的な物質群については最大 $\pm 20 \%$ 程度 67)の誤差を見積つておく必要がありそうである. 


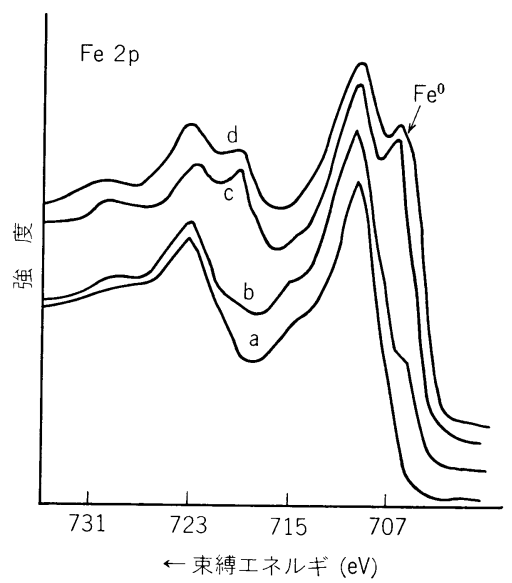

図15 $\mathrm{Ar}^{+}$スパッタリングによるフアイヤライト表 面の $\mathrm{Fe}$ スペクトルの変化. $\mathrm{a}$ ：スパッタリング前 b : $0.5 \mathrm{keV} 30 \mathrm{~min}$ スパッタリング, c : bを 1 $\mathrm{keV} 20 \mathrm{~min}$ スパッタリング， d：cを $1 \mathrm{keV}, 20$ $\min$ スパッタリング

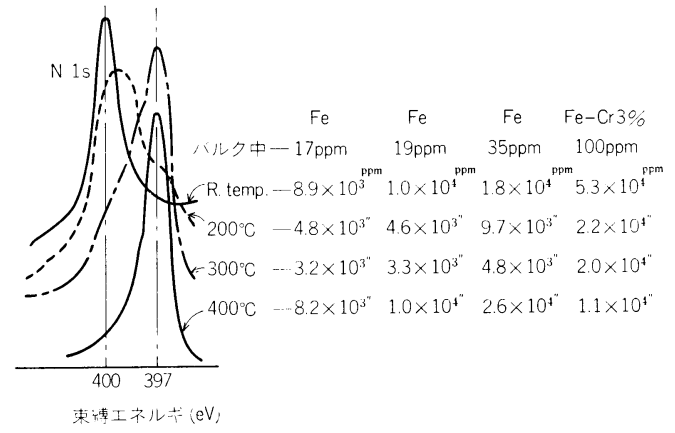

図16 鉄表面(鉄中)の $\mathrm{N}$ の加熱による変化の例

\section{5. その他の方法}

表面分析法として以上に述べた 3 つの方法以外は， EPMA を除いて未知試料を測定する場合に無力かある いはある程度の制限がある. そのためこれら 3 つの方法 と相補的に使用されて大きな効果がある。 また EPMA とこれら 3 つの方法と同等程度の 情報を与えても Soft X-Ray Appearance Potential Spectroscopy などのよ らに Instrumentation が未熟であつたり情報の種類や質 がこれら4つの方法に及ばない場合も多い.

ここでは，前に述べた 3 つの方法よりも深い範囲の表 面分析でとくに鉄鋼といらより Fe に応用できるメスバ ウワー分光法について触れておく. メスバゥワー分光法 のなかでも Conversion Electron Mössbauer Spectrometry (GEMS) がそれで, これは Fe の場合, $14.4 \mathrm{eV}$ の準位の $57 \mathrm{Fe}$ 原子核から再放出される転換電子（エネ ルギ $7.3 \mathrm{eV}$, 放出率 $90 \%$ ) を測定してメスバウワー効

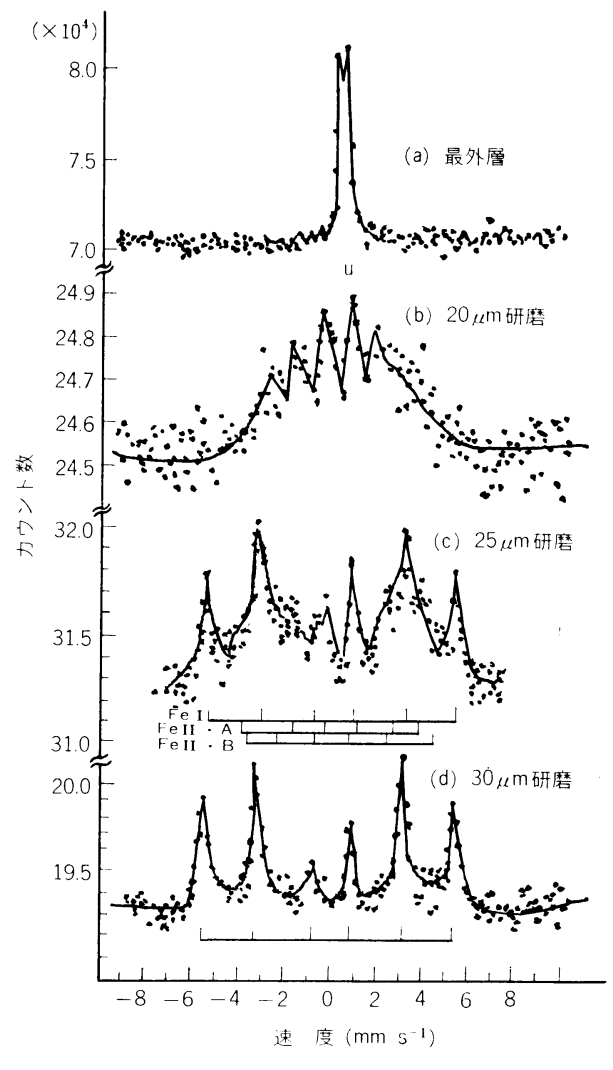

図17 ガス窒化した鋼表面のC E M S 68)

果を測定する方法である. 鉄化合物の表面 $1000 \AA$ 程度 の厚さまでの表面状態を測定するのに有効である ${ }^{68)}$. こ れはメスバウワー分光法の性格上 $\mathrm{Fe}$ と $\mathrm{Sn}$ の 2 元素以 外では鉄鋼に対する応用が考え難いが，この両元素とも 鉄鋼に関係が深いので注目してよいと思う.図 17 には ガスチツ化した鋼表面の CEMS で鋼の表面下 $20 \mu \mathrm{m} の$ 層は表面下 $25 \mu \mathrm{m}$ に存在する $\gamma^{\prime}-\mathrm{Fe}_{4} \mathrm{~N}$ と最表面層の $\varepsilon-$ $-\mathrm{Fe}_{4} \mathrm{~N}$ とも異なつて $\varepsilon$ 相と $\gamma^{\prime}$ 相の混相を示しているこ とがわかるという，一方ブリキ板の腐食に対してGEMS を応用した例も報告 ${ }^{69)}$ されている.

以上の他単に深さ方向の元素を平均的に数 $\mu \mathrm{m}$ のかな りの深さまで測定したい場合には Grimm Glow 放電に よるスパッタリングを発光などで観察することも手軽で 有効である ${ }^{70)}$.

以上のように表面分析法として, EPMA 以後広く応 用され，かつ，未知の試料に対して比較的スムーズに 応用できる 3 つの方法を重点に述べた.もちろん LaserRaman 分光法を始め, 寸でに前にかかげた諸方法をす べて述べて鉄鋼への応用の可能性や限界などについても 述べるべきであろらが，内容的に龙大となり，ともする と鉄鋼の表面分析より，一般的な表面物性測定法の集録 
となりがちなので本稿では 3 つの方法に重点を置いた。

これらの諸方法は EPMA のようにある程度確立された 手法として広く行きわたるにはもらしばらくの時間が必 要かとも思われる。 また最近話題になる SOR（シンク ロトロン軌道放射）も各実験室規模使用できるように 小型化するまでにはかなりの日時が必要と思われるの で, 当面の間分析電顕を含めて多くの表面分析手法が, 目的により使いわけられて行くものと思う。

\section{交献}

1) P. H. Holloway, G. E. McGuire: Appl. Surf, Sci., 4 (1980), p. 410

2) C. J. Powell: Appl. Surf. Sci., 1 (1978), p. 143

3 ) W. L. Baun : Appl. Surf. Sci, 4 (1980), p. 291

4) 大塚俊明, 工藤清勝, 佐藤教男: 日本金属学会誌 40 (1976), p. 124, 兑の他

5 ) 原 信義, 杉本克久: 日本金属学会誌, 43(1979), p. 992，元の他

6 ) 広川吉之助：鉄々鋼，57 (1971), p. 430

7 ) 広川吉之助：日本金属学会会報，11 (1972), p. 771

8 ) 広川吉之助：鉄と鋼，60 (1974), p. 1827

9 ) 佐藤公隆：分光研究, 29 (1980), p. 3

10）鹿又一郎, 早川和延：応用物理, 47 (1978), p. 348, 它の他

$11) K$. Sato, $K$. Suzubi, $R$. Matsumoto, and $S$. NAgAshima: Trans. Japan Inst. Metals, 18 (1977), p. 61

12）野村節生，戸所秀男，茄田 孜：分光研究， 27 (1978), p. 102, 穴の他

13) 例㫕ば, D. ChattarjI: The Theary of Auger Transitions (1976) [Akademic Press] その他

14) E. J. Scheiber, L. H. Germer, and C. D, Hartman: Rev. Sci, Inst., 31 (1960), p. 211

15) 例えば, A. Joshi, L. E. Davis, and P. W. Palmberg: Method of Surface Analyses, (1950), [Ilsovier sci. Press] その他

16) L. A. Harris: J. Appl. Phys, 39 (1968), p. 1419

17) C. R. Bruudle: J. Vac. Sci. Technol, 11 (1974), p. 212, 元の他

18) M. Gryzinsky: Phys. Rev., A138(1965), p. 336 穴他

19）小野雅敏，小林 尚：表面分析の定量化（日本金 属学会編，金属学会セミナー）(1978), p. 17 そ の他

20）小俣裕保，小川保之：日本金属学会誌，42 (1978), p. 1200, その他

21) $M$. Seo, $J . B$. Lumsden, $R$. $W$. Staehle: Surf. Sci., 50(1975), p. 541, 并の他

22) $H$. Shimizu, $M$. Ono, $K$. Nakayama, $M$. Yamada: Japan, J. Appl. Phys, Suppl 2(1974), p. 351
23）吉原一紘，倉橋正保，新居和嘉：日本金属学会誌 43(1979)，p. 409，元の他

24）寺坂正二, 土谷康夫, 新倉正和, 山田 真, 田中 淳一: 学振 1 委-No. 95 (昭和 51 年), p. 38

25) P. W. Palmberg: Anal. Chem., 45 (1973), $549 \mathrm{~A}$ その他

26）岡島義昭, 福井 寛, 戸所秀男, 針谷義雄：分析 化学, 29(1980), p. 351, 并の他

27) R. W. ReVIE, B. G. BAKER, J. O. M. BockRIS: J. Electrochem. Soc., 122(1975), p. 1460, 芒の 他

28) $H$. Tamura, $T$. Kondo, and $T$. Hirano: Proc. 6th, Inter. Conf. X-ray Optics and $T$. Microanalysis (ed. by $G$. SHINoda, et. al) (1972), p. 423 [University of Tokyo Press]

29) H. Liebel: J. Appl, Phys, 38 (1967), p. 5277

30) $H$. Nishimura and $J$. Ozano: Japan. J. Appl. Phys., 8 (1969), p. 1335

31) A. Benninghoven: Surf. Sci., 53(1975), p. 59ô 宗の他

32) K. Wiтtмоласк: Surf. Sci., 89 (1979), p. 668, その他

33）白岩俊男，藤野允克，村山順一郎，薄木智亮：学 振 141 委-No. 139 (昭和 52 年), p. 17 同上，学振第 141 委員会資料 No. 168(1979), p. 21

34）例光ば，吉岡芳明，草尾健司，小西交弥：学振 141 委-No. 216 (昭和 54 年), p. 95，元の他

35) $C$. A. Andersen and $J$. R. Hinthorne: Anal. Chem., 45(1973), p. 1421, その他

36) $R$. Castaing, $J . F$. Hennequin: Advance in Mass Spectrometry (ed. by $A$. QUAYEL) (1972) p. 419 Institute of Petroleum, London, 关の他

37) P. Joyle and J. F. Hennequin: J. Physique, 29 (19000), p. 243, その他

38) J. M. Schroeer: Surf, Sci, 34 (1973), p. 571

39) $H . W$. Werner: Advances in Applied Spectroscopy. (ed. Groue) 7A (1969), p. 239,

[Plenun Press] New York, Surf. 47 (1975), p. 301

40) A. Benninghoven and A. Muller: Phys. Lett., 40A (1972), p. 169, 穴の他

41) 例㫕ば, $T$. Ishitani, $H$. Tamura, and $T$. KonDo: Anal. Chem., 47 (1975), p. 1294 など

42) $H$. Kobayashi, $K$. Suzuki, $K$. Yukawa, $H$. Tamura, and $T$. Ishitani: Rev, Sci, Instrum, 48 (1977) p. 1289

43）角山浩三，大橋善治，鈴木敏子：川崎製鉄技報, 7 (1975), p. 1

44) A. E. Morgan, and $H . W$. Werner: Anal. Chem., 48 (1976), p. 699

45）白岩俊男，藤野允克，村山順一郎：住友金属, 26 (1974), p. 55

46) $K$. Tsunoyama, $Y$. Ohashi, and $T$. Suzuki: Anal. Chem., 48 (1976), p. 832, その他

47）柳沢義昭，鈴木堅市，小林尚：学振第 141 委員 
会ワーキンググループ報告（53．7．13)，p．43， その他

48) 小林 尚, 鈴木堅市, 柳沢義昭, 陽川憲一：学振 141 委-No. 137 (1977), p. 1, その他

49) ESCA Atomic, Molecular and Solid State Structure studied by Means of Electron Spectroscopy, $K$. Siegbahn et al.: Almquis \& Wiksells, Uppsala (1967), その他

50) 浅見勝彦：学位論交 (X線光電子分光法による鉄 クロム合金表面の研究） その他

51) 例えば, N. S. MaIntyre, D. G. Zetaik：J. Vac. Sci. Technol., 14 (1977), p. 181, 并の他

52) S. Storp and R. Holm: Surf. Sci., 68 (1977), p. 10 ， 穴の他

53) $M$. OKu and $K$. Hirokawa: J. Appl. Phep, 50 (1979), p. 6303, 奥 正興：学位論文（マンガ ソ，鉄，コバルト酸化物の $\mathrm{X}$ 線光電子スペクト ル）その他

54) $M$. Oku, $K$. Hirokawa, and $S$. Ikeda: J. Electron Spectrosc., 7 (1975), p. 465

55) S. Hüfuer, $R$. L. Cohen, and G. K. Werтнеiм: Physca Scripta, 5 (1972), p. 91

56) Lo I. Yin, S. Ghose, and I. Adler: Appl. Spectrosc., 26 (1972), p. 535

57) $K$. Hirokawa, $Y$. Yokokawa, and $M$. OkU: Surf. Interface Anal. 3 (1981) p. 81
58) 広川吉之助, 奥正 興，本多文洋：分析化学，26 (1977), T7

59) $F$. Honda and $K$. Hirokawa: J. Electron. Spectroc. 12 (1977), p. 313

60) $F$. Honda and $K$. Hirokawa: Talanta, 25 1978), p. 383

61）例えば, 藤野允克, 薄木智亮, 村山精一郎：学振 141 委-No. 211 (1979), p. 61, その他

62) K. Hirokawa, M. Oku: Z. anal. Chem., 285 (1977), p. 192

63) K. Hirokawa, M. Oku: Talanta, 26 (1979), p. 855

64) $K$. Hirokawa, T. Sato, and $M$. Oku: Z. Anal. Chem., 297 (1979), p. 393

65) M. F. EвEL: J. Electron Spectrosc., 5 (1974), p. 837

66) M. F. Ebel: Surf. Interface. Anal., 1 (1979), p. 58

67) $K$. Hirokawa, $Y$. Danzaki: Surf. Interface Anal. 2 (1980), p. 240

$68)$ 氏平祐輔，大數又茂，半田有通：分光研究， 28 (1979), p. 123, その他

69) 加藤明則, 遠藤和豊, 佐野博敏: 分析化学, 29 (1980), p. 708

70) 例えば, $M . E$. Waitlevertch, $J . K$. Hurwitz: Appl. Spectrosc., 30 (1976), p. 510, その他 